\title{
Do Film Festivals Attract Tourists?
}

\section{Graham KENDALL}

University of Nottingham Malaysia Campus

Jalan Broga, 43500 Semenyih Selangor Darul Ehsan Malaysia

Automated, Scheduling and Planning (ASAP) Research Group, School of Computer Science, University of Nottingham, UK

graham.kendall@nottingham.edu.my

Jimmy H. T. CHAN

Institute of International Business and Governance / The Open University of Hong Kong 30 Good Shepherd Street, Ho Man Tin, Kowloon, Hong Kong

htchan@ouhk.edu.hk

Matthew C. H. YEUNG

Institute of International Business and Governance / The Open University of Hong Kong 30 Good Shepherd Street, Ho Man Tin, Kowloon, Hong Kong

myeung@ouhk.edu.hk

Kuok Kei LAW

NUCB Business School

1-3-1 Nishiki Naka, Nagoya Japan 460-0003

kk_law@gsm.nucba.ac.jp 


\begin{abstract}
Hosting film festivals has become a prevailing practice to promote culture or festival tourism. Empirical studies on the relationship between cultural attendance and tourism demands, however, were mainly comprised of investigations of data of one or very few countries. In this study, by conducting dynamic panel data analysis, with secondary data across 80 countries collected, the effects of hosting film festivals on the number of inbound tourists were examined. While results informed the economic value of hosting film festivals, the positive effect was found to be more significant when festivals were hosted in art countries.
\end{abstract}

Keywords: Art tourism, Cultural tourism, Film, Festival tourism, Tourism economics, Tourist

\title{
Introduction
}

Festivalization is now a rapidly developing global phenomenon in tourism (Bennett, Taylor, \& Woodward, 2014). Lee, Kyle, and Scott (2012) suggested that festivals could arise attendants' positive emotion which could be salient in nature, encouraging future return tourists. Among the different festivals, film festivals have been gaining popularity (Wong, 2011). It was reported, for example, that the 2017 Sundance Film Festival hosted in Utah, U.S. generated an economic impact of USD 151.5 million (Sundance Institute, 2017).

Against such a background, this study explores the economic implications of film festivals. We employed the central market theory (Christaller \& Baskin, 1966) to guide our exploration. An operating premise of this theory is that a central market place with equal transportation costs in all directions can exist to efficiently supply goods and service to the neighboring cities or countries in which consumers are assumed to be homogeneous. Hosting a film festival event at 
the central place provides a new locational feature that is essentially complementary to that of the focal point, which would provide stimulus to the tourism industry as well as the economy of the location.

The findings will provide implications to practitioners of film industries, organizers of film festivals and government officials in order to make more informed decisions in joining, organizing and promoting film festivals.

\section{Methodology}

In this study, the relationship between hosting film festivals and tourism demand was empirically examined. Previous models tended to explain the variations in inbound arrivals of a particular country with a set of regressors. There has not been, however, a consensus on the selection of independent variables and the specification of the base model for this purpose. Only a few isolated efforts have been made to model tourism demand for a group of countries (Song \& $\mathrm{Li}, 2008$ ). More than $95 \%$ of studies in this regard were based on dyadic data that restricted the applicability of the findings to a single country.

Moreover, to the best of our knowledge, there has been no investigation on tourism demand elasticities with a special emphasis on investigating the number of film festivals (FILM $\left.\boldsymbol{M}_{\boldsymbol{i t}}\right)$ as a determinant of tourist arrivals (Inbound $i$ ). We propose that the number of inbound trips to the tourist receiving country, $i$, is determined by (a) the supply of tourists from the all countries which is the number of the world's outbound tourists minus the outbound tourists of the tourist receiving country $\left(\boldsymbol{O u t w}_{\boldsymbol{t}}-\boldsymbol{O u t w}_{i t}\right),(\mathrm{b})$ three attracting features of the receiving country $i$ - GDP per capita $\left(\boldsymbol{G D P} \boldsymbol{C}_{i t}\right)$, real exchange rate $\left(\boldsymbol{R E R} \boldsymbol{R}_{i t}\right)$ and political stability $\left(\boldsymbol{P S t} \boldsymbol{b}_{i t}\right)$. The included variables mirrored those of Pham, Nghiem, and Dwyer (2017) with political stability added 
because political instability may generate negative publicity, resulting in the inevitable decrease in tourist arrivals (Causevic \& Lynch, 2013; Ingram, Tabari, \& Watthanakhomprathip, 2013). Our model is illustrated in Equation 1 below and the data sources of the different factors are summarized in Table 1.

$$
\begin{aligned}
\text { Inbound }_{i t}=\beta_{1} & +\rho \text { Inbound }_{i, t-1}+\left(\text { Outw }_{t}-\text { Outw }_{i t}\right) \beta_{2}+\boldsymbol{G D P C}_{i t} \beta_{3} \\
& + \text { PStb }_{i t} \beta_{4}+\boldsymbol{R E R}_{i t} \beta_{5}+\text { FILM }_{i t} \beta_{6}+u_{i}+\varepsilon_{i t}
\end{aligned}
$$

We extracted from Euromonitor International (EMI) which provides arrival data for 84 major countries from 2001 to 2016. Inbound tourism flows comprise the activities of a nonresident visitors within the country of reference on an inbound tourism trip, disregarding border, seasonal, short-term workers, and long-term students as visitors. EMI estimates the outbound tourism flows on the basis of data supplied by each of the destination countries, not departure data provided by the country of reference. The listwise deletion applied for handling missing data results in the inclusion of 80 countries in the analysis. The number of sampled countries by regions are as follow: Asia Pacific (18), Australasia (2), Eastern Europe (13), Latin America (13), Middle East and Africa (15), North America (2), Western Europe (17).

[Table 1]

Equation 1 includes the lagged dependent variable on the RHS of the equation to indicate the effect of word-of-mouth and habitual travel choice. Modelling such an effect with panel data, by construction, requires an effective estimation approach whose consistent estimator does not lead to Nickell's bias (1981). We adopted Arellano and Bond's GMM difference estimator to estimate the parameter of the equation.

We fitted Equation 1 with three basic functional forms: linear, log-linear and semi-log, and both the log-linear and semi-log models yielded a very poor fit to the collected data. The 
significance of variables did not resemble what were suggested by prior studies. The linear functional form was the most adequate as it yielded a satisfactory goodness-of-fit and performed best in terms of signs of the coefficients and statistical significance of the coefficients. Table 2 displays the estimates.

[Table 2]

To further diagnose the specifications of the model, we employed Hansen's (1982) test of over-identifying restrictions to evaluate the validity of the instruments. The test statistics did not reject the null hypothesis that the moment conditions were invalid at any conventional significance level. To evaluate the consistency of estimators, we tested if the differenced residuals showed evidence of significant or insignificant negative first-order serial correlation. The AR(1) tests rejected the null hypothesis of no first-order serial correlation in the differenced residuals. The $\mathrm{AR}(2)$ tests did not reject the null hypothesis of no second-order serial correlation in the differenced residuals. These are indications of correct model specifications.

\section{Results}

The coefficient of Film was 267, which means for each film festival, on average, the hosting country can attract additional 267 tourists in the short-run and 1,045 [i.e. 267/(1-0.7459)] tourists in the long-run. It is difficult to judge objectively the economic impact of the additional tourists. First, the events of this sort transform many high net worth individuals such as the actors and actresses and their crew members into travelers. Second, they contribute to tourism development in the long run by generating recurring visits to the host countries. In addition to the income generated from the specific travel of the individuals, the host countries are likely to receive high 
media coverage and may eventually develop into event capitals. Hence, while the estimated head count appears to be small, the economic impact needs to be further researched.

The comparison between the effects of hosting film festivals in Art Countries vs. non-Art Countries was reported in Model 2. We define whether or not a country is an Art Country from studying five sources (Condé Nast Traveler's Survey on the World's Best Cities for Arts and Culture, Study by TotallyMoney.com that analyzed data from TripAdvisor, Michelin's Travel Guide, UNESCO World Heritage Sites and New York Times' webpage for Art and Culture Journey). These sources identify destinations with arts and cultural scenes by a good range of methods (e.g. expert reports, number of art and cultural heritage). We included 27 countries as Art Countries whose art-and-cultural destinations have received more than three recommendations from the five sources (see Table 3).

[Table 3]

The coefficient of the dummy variable for Art Countries $\left(D_{A R T}\right)$ is 322 and it is statistical significant, suggesting that Art Countries are more popular tourist destination when compared to Non-Art countries in general. More importantly, the coefficient of the interaction term between the Art Countries Dummy and the number of inbound arrival is positive and also statistically significant, suggesting that the effect of hosting film festivals in Art Countries on tourism demand is greater than hosting film festival in Non-Art Countries. In the short-run, on average, Art Countries generate four times as much inbound arrival as Non-Art Countries do per film festival. In the long-run, the differential effect goes up to five times.

\section{Conclusion}


In the tourism demand literature, cultural resources have been recognized as a factor attracting greater flows of tourism. The attention on the economic contributions of film festivals, however, has not been specifically explored empirically. Our study provides empirical evidence to support the economic contribution of the film industry in terms of tourism demands. Although the analysis provided statistical evidence, the size of the estimates was rather low. Future research can explore the effects of one-time film festival on tourism demand against those of film festivals' that are organized periodically. The evidence of the present study also leads to the needs for the development of cultural districts for the film industry.

\section{References}

Antolí-Calleja, M., Orduna-Malea, E., \& Ontalba-Ruipérez, J-A. (2016). Customised content and impact in Website evaluation models: the case of international film festivals. Information Research, 21(1), paper 704. Retrieved from http://InformationR.net/ir/21-1/paper704.html. Bennett, A., Taylor, J., \& Woodward, I. (2014). The Festivalization of Culture. Ashgate.

Causevic, S., \& Lynch, P. A. (2013). Political (In) Stability and its Influence on Tourism Development: The Case of Bosnia and Herzegovina. Tourism Management, 34, 145-157.

Christaller, W., \& Baskin, C. W. (1966). Central Places in Southern Germany. Englewood Cliffs, N.J.: Prentice-Hall.

Follows, S. (2013). Film Festival Pt 1: The Truths Behind Film Festivals, 19 August, available at https://stephenfollows.com/many-film-festivals-are-in-the-world, accessed Nov 2018

Hansen, L. P. (1982). Large Sample Properties of Generalised Method of Moments Estimators. Econometrica, 50(4), 1029-1054. 
Ingram, H., Tabari, S., \& Watthanakhomprathip, W. (2013). The impact of political instability on tourism: case of Thailand. Worldwide Hospitality and Tourism Themes, 5(1), 92-103.

Lee, J., Kyle, G., \& Scott, D. (2012). The mediating effect of place attachment on the relationships between festival satisfaction and loyalty to the festival hosting destination. Journal of Travel Research, 51(6), 754-767.

Nickell, S. (1981). Biases in dynamic panel models with fixed effects. Econometrica, 49(6), $1417-1426$.

Pham, T., Nghiem, S., \& Dwyer, L. (2017). The determinants of Chinese visitors to Australia: A dynamic demand analysis. Tourism Management, 63, 268-276.

Song, H., \& Li, G. (2008). Tourism demand modelling and forecasting-A review of recent research. Tourism Management, 29(2), 203-220.

Sundance Institute (2017). http://www.sundance.org/now.

Wong, C. H-Y. (2011). Film Festivals: Culture, People, and Power on the Global Screen. New Brunswick, New Jersey, and London: Rutgers University Press. 
Table 1. Variable Descriptions and Data Sources

\begin{tabular}{|c|c|c|}
\hline Variable & Description & Source: \\
\hline Inbound $_{i t}$ & $\begin{array}{l}\text { The number of inbound trips to the } \\
\text { tourist receiving country } i \text { at time } t\end{array}$ & \multirow{2}{*}{$\begin{array}{l}\text { Euromonitor International's Travel } \\
\text { sources including data from World } \\
\text { Tourism Organization and local } \\
\text { tourism boards }\end{array}$} \\
\hline $\begin{array}{l}\text { Outwt } \\
\text { Outw }_{i t}\end{array}$ & $\begin{array}{l}\text { The number outbound trips from all } \\
\text { country and from the tourist receiving } \\
\text { country, respectively }\end{array}$ & \\
\hline$G D P C_{i t}$ & Per capita real gross domestic product & $\begin{array}{ll}\text { Euromonitor International from } \\
\text { national statistics }\end{array}$ \\
\hline$P S t b_{i t}$ & $\begin{array}{l}\text { Political Stability and Absence of } \\
\text { Violence/Terrorism }^{\mathrm{a}}\end{array}$ & $\begin{array}{l}\text { Worldwide Governance Indicators } \\
\text { from The World Bank }\end{array}$ \\
\hline$R E R_{i t}$ & PPP real exchange rate & World Bank's Estimations \\
\hline FILM $_{i t}$ & The number of film festivals was held & $\begin{array}{l}\text { http://www.bestinfest.com/festivallist. } \\
\text { html }^{\text {b }}\end{array}$ \\
\hline
\end{tabular}

a Political Stability and Absence of Violence/Terrorism measures perceptions of the likelihood of political instability and/or politically- motivated violence, including terrorism. Estimate gives the country's score on the aggregate indicator, in units of a standard normal distribution, i.e. ranging from approximately -2.5 to 2.5 (https://datacatalog.worldbank.org/political-stability-and-absence-violenceterrorism-estimate). ${ }^{\mathrm{b}}$ Bestinfest.com has been referred to as the world's largest film festival list (Antolí-Calleja, Orduna-Malea, \& Ontalba-Ruipérez, 2016) and the most accurate data source (Follows, 2013) for film festival research. 
Table 2. The Effect of Film Festival on Tourism Demand

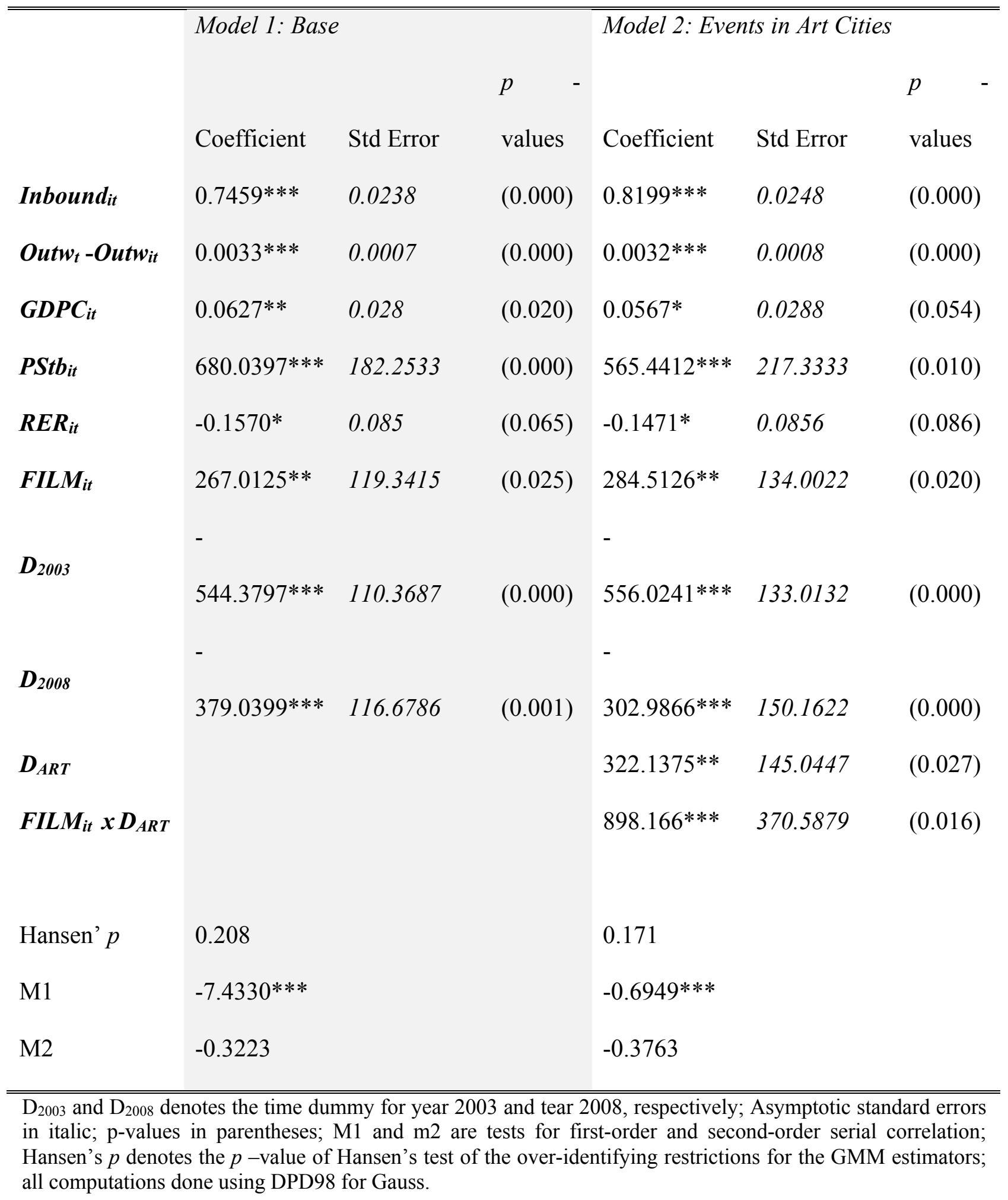


Table 3. Recommended Destinations with Arts and Cultural Scenes

\begin{tabular}{|c|c|c|c|c|c|}
\hline Countries & UNESCO & $\begin{array}{l}\text { Tripadvisor Data } \\
\text { analyzed by } \\
\text { TotallyMoney.co } \\
\text { m } \\
\end{array}$ & $\begin{array}{c}\text { Condé Nast } \\
\text { Traveler's } \\
\text { Survey }\end{array}$ & NY Times & $\begin{array}{c}\text { Michelin Travel } \\
\text { Guide }\end{array}$ \\
\hline Australia & 凶 & & & 凶 & 凶 \\
\hline Austria & 凶 & & 凶 & & 凶 \\
\hline Canada & 凶 & 凶 & & 凶 & $凶$ \\
\hline China & 凶 & 凶 & & & 凶 \\
\hline Czechia & 凶 & 凶 & & & 凶 \\
\hline Egypt & 凶 & & & 凶 & $凶$ \\
\hline Ethiopia & 凶 & & & 凶 & 凶 \\
\hline France & 凶 & $凶$ & 凶 & 凶 & 凶 \\
\hline Germany & 凶 & 凶 & & 凶 & 凶 \\
\hline Greece & $凶$ & & 凶 & 凶 & 凶 \\
\hline Hungary & 凶 & & & 凶 & 凶 \\
\hline India & 凶 & 凶 & & 凶 & 凶 \\
\hline Israel & 凶 & & 凶 & & 凶 \\
\hline Italy & 凶 & $凶$ & 凶 & 凶 & 凶 \\
\hline Japan & 凶 & 凶 & 凶 & & 凶 \\
\hline Jordan & 凶 & 凶 & & 凶 & 凶 \\
\hline Korea & 凶 & 凶 & & & 凶 \\
\hline Mexico & 凶 & & 凶 & 凶 & 凶 \\
\hline Morocco & 凶 & & & 凶 & 凶 \\
\hline Netherlands & 凶 & 凶 & & 凶 & 凶 \\
\hline Russia & 凶 & & & 凶 & 凶 \\
\hline Spain & $凶$ & 凶 & & 凶 & 凶 \\
\hline Switzerland & 凶 & & & 凶 & 凶 \\
\hline Thailand & & 凶 & & 凶 & 凶 \\
\hline Turkey & 凶 & 凶 & $凶$ & & 凶 \\
\hline UK & $凶$ & $凶$ & $凶$ & 凶 & 凶 \\
\hline USA & 凶 & 凶 & 凶 & 凶 & 凶 \\
\hline
\end{tabular}

